Comets Faye and Barnard.-The following ephemerides for these objects for Berlin midnight are in continuation of those given in NATURE, vol. xxxviii. p. 626 :-

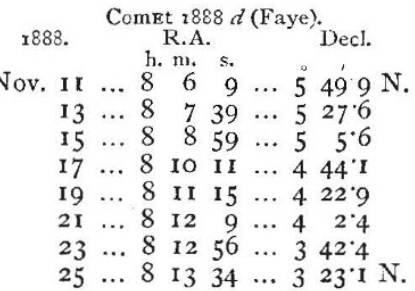

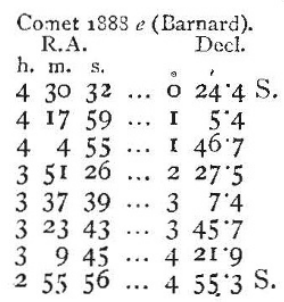

Discovery of a NFw Comet.-Mr. E. E. Barnard, Lick Observatory, Mount Hamilton, discovered a new comet on October 30 (local time). Place at October 3I.0399 G.M.T., R.A. 9h. $43 \mathrm{~m} .22 \cdot 2 \mathrm{~s}$; Decl. $15^{\circ} 18^{\prime} 52^{\prime \prime} \mathrm{S}$. Vaily motion, R.A. + Im. 32s.; Decl. $9^{\prime} n$. Physical appearance : slightly elongated; $\mathrm{I}^{\prime}$ in diameter ; $\mathbf{I} \mathbf{I}$ th magnitide, or fainter; strong central condensation.

\section{ASTRONOMICAL PHENOMENA FOR THE WEEK 1888 NOVEMBER II-I7.}

( $F$ OR the reckoning of time the civil day, commencing at Greenwich mean midnight, counting the hours on to 24 , is here employed.)

\section{At Greenwich on November if}

Sun rises, 7h. $14 \mathrm{~m}$.; souths, I Ih. $44 \mathrm{~m}$. 13.23 . ; sets, $16 \mathrm{~h} .14 \mathrm{~m}$. : right asc. on meridian, I 5 h. $84^{\circ} \mathrm{m}$; decl. $17^{\circ} 38^{\prime} \mathrm{S}$. Sidereal Time at Sunset, Igh. $39 \mathrm{~m}$.

Moon (at First Quarter November 10, 16h.) rises, 14h. 7m.; souths I 9 h. Om.; sets, oh. $2 \mathrm{~m} .{ }^{*}$ : right asc. on meridian, $22 \mathrm{~h} .25^{\circ}{ }^{\circ} \mathrm{m}$.; decl. $13^{\circ} 20^{\prime} \mathrm{S}$.

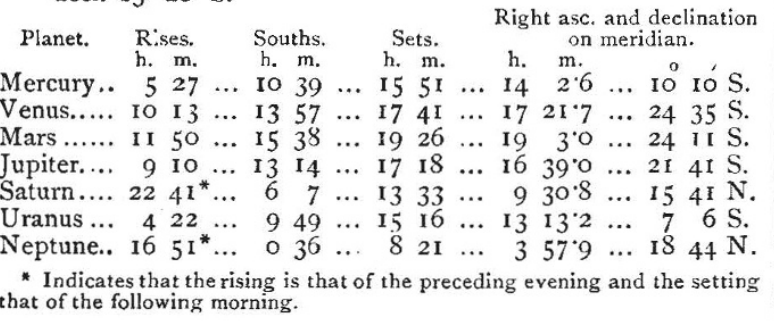

Occultations of Stars by the Moon (visible at Greenwich).

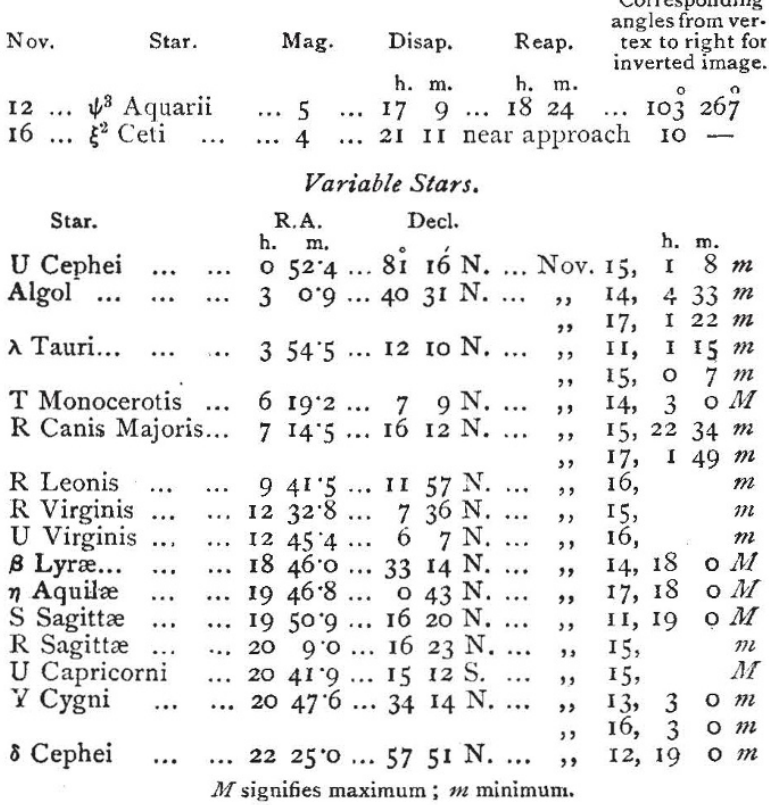

Nov. $h$.

I3 ... I3 ... Venus at greatest distance from the Sun.

$\begin{array}{lllll}17 & \ldots & 4 & \ldots & \text { Mercury at greatest elongation from the Sun }\end{array}$ $19^{\circ}$ east.

\section{Meteor-Showers.}

The principal periodic shower of the week is that of the Leonids, max. November I 4 , radiant R.A. $149^{\circ}$, Decl. $22^{\circ}$ N. but no great display is to be expected this year or for several years to come. Other showers are as follows :-

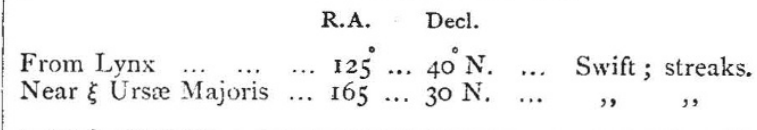

\section{GEOGRAPHICAL NOTES.}

THE great Constantine Medal was awarded this year by the Russian Geographical Society to Prof. Romanovsky for his geological work in Russian Turkestan. For more than five years the learned Professor explored varions parts of Turkestan, and thus laid the first foundations for the geological knowledge of this region. His first work, "Materials for the Geology of Turkestan," was published in 1876, and it contained the description of eighty-eight species of fossil animals (of which thirty-four were new species) and fourteen species of plants helonging to the Carboniferous, Triassic, Jurassic, and Chalk deposits of Turkestan; the Silurian and Devonian deposits of the region being so greatly metamorphosed as to have most of their fossils destroyed. This first work was soon followed by papers contributed to the Verhandlungen of the St. Petersburg Mineralogical Society, in which papers Prof. Romanovsky described the fossils of the Ferghana deposits (Upper Chalk, characterized by their richness in Ostrea, some of which belong to new genera), and the Sarvadan brown-coals, which contain the new lizard Bruntozoum tianschanicum, and are of the same age as the Connecticut Trias Sandstone. The second part of the "Materials for the Geology of Turkestan," published by Prof. Romanovsky, contains the description of all the palæontological collections gathered in Turkestan by MM. Mushketoff, Syevertsoff, Barbot-de-Marny, and Okladnykh ; and no less than 144 species of fossils (of which forty-nine are new) have been clescribed in this second instalment of the "Materials." It was precisely the palixontological work of Prof. Romanovsky which enabled M. Mushketoff to arrive at the remarkable general conclusions as to the great features of the geology of Turkestan, which are embodied in his capital work, "Turkestan," and which rendered it possible for both geologists to draw up the geological map which illustrates it.

AT the same sitting the great medal of Count Litke was awarded to Th. P. Köppen for his work in botanical and zoological geography. His work on the distribution of Conifers in Russia, published in 1885 , is an exhaustive inquiry into the subject, and his numerous monographs on the distribution of insects in Russia, as well as of the squirrel and the stag, as also his monographs about the Siberian cedar, the Scotch fir, the larch, the Juniperus, and so on, are most valuable contributions to the botanical and zoological geography of Russia; while his last work on the birth-places of the Indo-Europeans and the Finns and Ugrians (published in the Russian Journal of the Ministry of Public Education for I 886), although made in a new direction, is an important contribution to this much debated subject. Large gold medal; were awarded to Prof. M. M. Kovalevsky for his "Modern Customs and Old Iaw : the Customary Law of the Ossetes"; to Prof. Vs. Th. Miller for his "Ossetian Studies"; and to M. Pirogoff for a statistical work about Kostroma. A small gold medal was awarded to L. P. Zagursky, to whom the ethnography of the Caucasus is indebted for so many valuable works, and all ethnographers will be grateful for his endeavours to save from oblivion and to con. tinue the works of Baron Uslar, which undoubtedly are the most serious researches ever made into the study of Caucasian languages. Gold medals were also awarded to A. S. Vilkitzky for his determinations of the length of pendulum on Novaya Zemlya and at Archangelsk; to N. Y. Dinnik for explorations in Northern Caucasia ; and to D. Bulgakovsky for a manuscript work on the inhabitants of the Pinsk marshy tracts. Nineteen silver medals were awarded for various geographical works of less importance. 